\title{
Investigasi Bidang Gelincir Tanah Longsor Menggunakan Metode Geolistrik Konfigurasi Dipol-dipol Sebagai Upaya Mitigasi Bencana Alam di Kabupaten Minahasa
}

\author{
As'aria*,Seni H.J.Tongkukuta,Gerald H.Tamuntuana \\ aJurusan Fisika, FMIPA, Unsrat, Manado
}

KATA KUNCI

Bidang gelincir,

Tanah longsor

Dipol-dipol

\begin{abstract}
A B S TR A K
Kondisi geografis Kabupaten Minahasa merupakan pegunungan dan perbukitan, jalan utama sebagai sarana akses transportasi yang menghubungan daerah bagian selatan dengan ibukota Provinsi Manado berada di lereng-lereng pegunungan ini. Telah terjadi longsor di beberapa tempat dan menutupi jalan utama. Salah satu faktor penyebab longsoran yang sangat berpengaruh adalah bidang gelincir atau bidang geser. Guna mengantisipasi terjadinya bencana tanah longsor maka sangat penting untuk dilakukan eksplorasi geolistrik untuk inventarisasi data dan informasi potensi terjadinya bencana tanah longsor. Telah dilakukan eksplorasi untuk mengetahui potensi tanah longsor dengan menginvestigasi keberadaan bidang gelincir di Jalan Manado Tomohon. Eksplorasi menggunakan metode geolistrik resistivitas konfigurasi dipol-dipol. Pengukuran dilakukan menggunakan resistivitymeter MAE X612 EM pada 4 lintasan, lintasan 1-4 menggunakan 24 elektroda dan spasi 10 m dengan panjang lintasan $240 \mathrm{~m}$. Data pengukuran diolah menggunakan software RES2DINV, hasil pengolahan berupa tampang lintang resistivitas 2 dimensi. Bidang gelincir diidentifikasi dengan resistivitas (30 - 215) $\Omega \mathrm{m}$, yang merupakan lapisan lempung pasiran. Bidang gelincir ditemukan pada semua lintasan, pada lintasan 1, 3 dan 4 terdapat 2 lapisan dengan kedalaman sampai $23 \mathrm{~m}$. Lintasan 2 bidang gelincir teridentifikasi tersebar pada 3 lokasi dengan kedalaman mencapai $20 \mathrm{~m}$.
\end{abstract}

K E Y W O R D S

Slip surface

Landslides

Dipole-dipole
A B S T R A C T

The geographical conditions of Minahasa Regency are mountains and hills, the main road as a means of transportation access that connects the southern region with the capital of Manado Province on these mountain slopes. Landslides have occurred in several places and covered the main road. One of the most influential factors for landslides is the slip surface or shear surface. To anticipate landslides, it is very important to explore geoelectricity for an inventory of data and information on potential landslides. Exploration has been carried out to determine the potential of landslides by investigating the existence of slip surface on Jalan Manado Tomohon. Exploration using geoelectric resistivity method dipole-dipole configuration. Measurements were made using MAE X612 EM resistivitymeter on 4 lines, line 1-4 using 24 electrodes and $10 \mathrm{~m}$ spacing with $240 \mathrm{~m}$ line length. Measurement data is processed using RES2DINV software, the results of processing are 2-dimensional resistivity crossection. The slip surface is identified by resistivity (30 - 215) $\Omega \mathrm{m}$, which is a layer of sandy clay. The slip surface is found on all lines, on lines 1,3 and 4 there are 2 layers with a depth of up to $23 \mathrm{~m}$. Slip surface at line 2 are identified spreading over 3 locations with depths reaching $20 \mathrm{~m}$.
TERSEDIA ONLINE

01 Agustus 2018

\section{Pendahuluan}

Pembangunan yang semakin giat dan pengembangan pertanian yang semakin maju pada saat ini menimbulkan banyak dampak positif pada sektor ekonomi dan sosial budaya.Selain itu juga mengakibatkan dampak negatif, pemotongan bukit untuk pembangunan jalan, penebangan hutan guna pengembangan lahan pertanian merubah

*Corresponding author: Jurusan Fisika FMIPA UNSRAT, Jl. Kampus Unsrat, Manado, Indonesia 95115; Email address: as.ari2222@yahoo.co.id Published by FMIPA UNSRAT (2018) 
bentang alam. Perubahan ini menjadikan keseimbangan terganggu, gaya ikat lapisan batuan berkurang, terbentuknya bidang gelincir pada area antar lapisan, yang dapat mengakibatkan tanah longsor. Salah satu faktor penyebab longsoran yang sangat berpengaruh adalah bidang gelincir (slip surface) atau bidang geser (shear surface). Pada umumnya tanah yang mengalami longsoran akan bergerak di atas bidang gelincir tersebut [Sugito et al, 2010].

Terutama pada musim hujan dimana massa tanah di atas bidang gelincir bertambah dan terjadinya infiltrasi air hujan ke dalam tanah semakin besar. Pengaruh curah hujan yang sulit diukur karena tergantung pada beberapa faktor, termasuk heterogenitas tanah (kekuatan dan permeabilitas properti) dan iklim regional. Telah diakui dalam literatur bahwa curah hujan dapat menjadi faktor predisposisi dalam aktivasi slip tanah(Wieczorek, 1987 dalam Aleotti, 2004).

Bidang gelincir dapat diinvestigasi dengan menggunakan berbagai metode geofisika, metode geolistrik tahanan jenis merupakan metode geofisika yang banyak digunakan untuk mengekspolrasi permukaan tanah yang mempunyai potensi terjadinya tanah longsor.Investigasi slip permukaan tanah longsor menggunakan metode tahanan geolistrik telah dilakukan di Desa Kebarongan, Kecamatan Kemranjen, Kabupaten Banyumas. Hasil interpretasi menunjukkan bahwa pada litologi Desa Kebarongan terdiri dari empat lapisan tanah atas yaitu, tanah liat berpasir, tanah liat basah dan tanah liat berpasir. Slip permukaan adalah tanah liat basah dengan kedalaman 10,31 sampai 14,21 m (Sugito et al, 2010).

Pada awal tahun 2018 di Sulawesi Utara telah terjadi cuaca ekstrem, yang mengakibatkan terjadinya tanah longsor di beberapa tempat.Longsoran ini menutupi jalan sehingga akses transportasi darat terganggu selama beberapa waktu.Sehingga dari segi ekonomi dan sosial sangat merugikan, kodisi yang demikian dapat diantisipasi jika data dan informasi daerah rawan sudah terinventarisasi dengan baik.Identifikasi yang akurat dan cepat tentang daerah longsor adalah basis untuk memproses dan menganalisis kejadian darurat bencana (Ao et al, 2014).

Tanah longsor merupakan salah satu bencana alam yang merusak besar di daerah pegunungan, diaktifkan terutama di bawah pengaruh gempa bumi dan curah hujan.Ini bencana alam telah terjadi di semua bagian dari Himachal Pradesh serta di daerah yang sangat berbukit.Interaksi antara geologi lokal dan kondisi iklim jangka panjang hasil di bentang alam yang berbeda secara signifikan dengan berbagai tingkat kerentanan terhadap tanah geser. Meskipun tanah longsor yang fenomena lokal, namun total kerugian nyawa dan harta benda akibat tanah longsor jauh lebih besar daripada bahaya lainnya (Pareta dan Pareta, 2012). Penelitian ini sebagai langkah untuk mitigasi bencana alam dan mensuplai informasi tentang potensi tanah longsor ke penentu kebijakan di pemerintah daerah Sulawesi Utara.

Tanah longsor terjadi dikarenakan bertambahnya massa pada tanah, kemiringan dan terdapatnya bidang luncuran. Pada waktu musim kemarau yang panjang, tanah akan menjdi sangat kering dan berpori, sehingga pada waktu terjadi peralihan musim dari kemarau ke hujan tanah akan menyerap banyak air dan akan mengisi pori-pori tanah yang terbentuk waktu musim kemarau (Vardoulakis, 2002).

\section{Hasil dan Pembahasan}

Eksplorasi metode geolistrik tahanan jenis merupakan metode eksplorasi geofisika yang ramah lingkungan dan tidak merusak.Pengambilan data dilakukan dengan mengalirkan arus listrik ke dalam tanah dari permukaan dengan mengggunakan dua buah elektroda. Selain itu terdapat dua elektroda lain yang berfungsi sebagai pengukur beda potensial listrik. Aturan posisi keempat elektroda yang digunakan adalah bentangan konfigurasi Dipol dipol. Data yang diperoleh dari pengukuran ini adalah kuat arus (I), beda potensial (V) dan jarak spasi a. Data topografi diperoleh dengan menggunakan GPS.

Penelitian dilakukan di Desa Tinoor Kecamatan Tomohon Kabupaten Minahasa (Gambar 1). Studi pendahuluan dan orientasi lapangan menemukan bahwa daerah ini memiliki kemiringan yang cukup curam, dilalui jalan yang merupakan akses utama penghubung dengan Kota Manado, terdapat beberapa rumah baik di sebelah atas dan bawah di tepi jalan raya. Dirancang desain survey sperti pada Gambar 1, lintasan pengukuran 4 buah, spasi elektroda $2 \mathrm{~m}$, panjang bentangan $72 \mathrm{~m}$. Akuisisi data geolistrik menggunakan alat multichannel and multielectrode resistivity and IP meter MAE X612EM.

Eksplorasi geofisika Metode Geolistrik Konfigurasi Dipol-dipol Data hasil ukur resistivitymeter diolah dengan menggunaka software Res2Dinv.Pada konfigurasi Dipol-dipol, dua elektroda arus dan dua elektroda potensial ditempatkan terpisah dengan jarak na, sedangkan jarak masing-masing elektroda a. Pengukuran dilakukan dengan memindahkan elektroda potensial pada suatu penampang dengan elektroda arus tetap, kemudian pemindahan elektroda arus pada spasi $\mathrm{n}$ berikutnya diikuti oleh pemindahan elektroda potensial sepanjang lintasan seterusnya hingga pengukuran elektroda arus pada titik terakhir di lintasan itu (Seaton dan Burbey, 2002). Husain dkk, 2017 telah melakukan pengukuran lapisan bawah permukaan tanah dengan menggunakan metode geolistrik tahanan jenis konfigurasi dipol dipol untuk memetakan air tanah di Universitas sam Ratulangi. Nilai resistivitas yang merupakan lapisan pembawa air bernilai 25,93 $\Omega \mathrm{m}$. Diperoleh posisi akuifer air tanah di area penelitian yaitu padalintasan 1,3, 5,7, 8 dan 9 . 


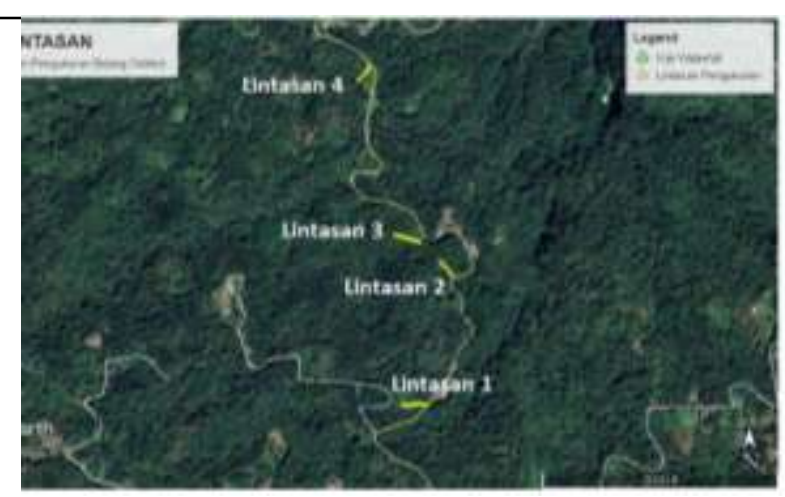

Gambar 1. Peta lintasan pengukuran

Hasil perhitungan nilai tahanan jenis semu dibawah lintasan ukur hingga kedalaman tertentu sesuai dengan panjang bentangan yang digunakan, semakin panjang bentangan maka semakin dalam target yang dapat diketahui.Hasil olahan berupa tampang llintang resistivitas 2 dimensi yang menggambarkan kondisi lapisan tanah bawah permukaan.Nilai tahanan jenis yang relatif tinggi berasosiasi dengan batuan kering, batuan beku, bedrock ataupun lainnya.Sedangkan nilai tahanan jenis yang relatif rendah berasosiasi dengan batuan basah, lapisan penutup basah, saluran air/celah/retakan yang mengandung air ataupun logam. Sehingga dengan mengetahui jenis batuan atau geologi lokal setempat, nilai-nilai tahanan jenis tersebut dapat dikonversikan ke jenis batuan atau tanah atau struktur bawah permukaan. Hasil perhitungan nilai tahanan jenis semu dibawah lintasan ukur hingga kedalaman tertentu sesuai dengan panjang bentangan yang digunakan, semakin panjang bentangan maka semakin dalam target yang dapat diketahui.Hasil olahan berupa tampang llintang resistivitas 2 dimensi yang menggambarkan kondisi lapisan tanah bawah permukaan.Nilai tahanan jenis yang relatif tinggi berasosiasi dengan batuan kering, batuan beku, bedrock ataupun lainnya.Sedangkan nilai tahanan jenis yang relatif rendah berasosiasi dengan batuan basah, lapisan penutup basah, saluran air/celah/retakan yang mengandung air ataupun logam. Sehingga dengan mengetahui jenis batuan atau geologi lokal setempat, nilai-nilai tahanan jenis tersebut dapat dikonversikan ke jenis batuan atau tanah atau struktur bawah permukaan.

\section{Hasil dan Pembahasan}

Lapisan lempung yang merupakan penyusun bidang gelincir ditemukan pada tiap lintasan. Kondisi geologi daerah penelitian terdiri atas tanah liat, lempung pasiran dan batu-batu besar yang terbenam dalam tanah. Lintasan 1 memperlihatkan keberadaan lapisan lempung, pada Gambar 2.Diperoleh lapisan lempung yang merupakan penyusun bidang gelincir pada tiap lintasan. Kondisi geologi daerah penelitian terdiri atas tanah liat, lempung pasiran dan batu-batu besar yang terbenam dalam tanah.

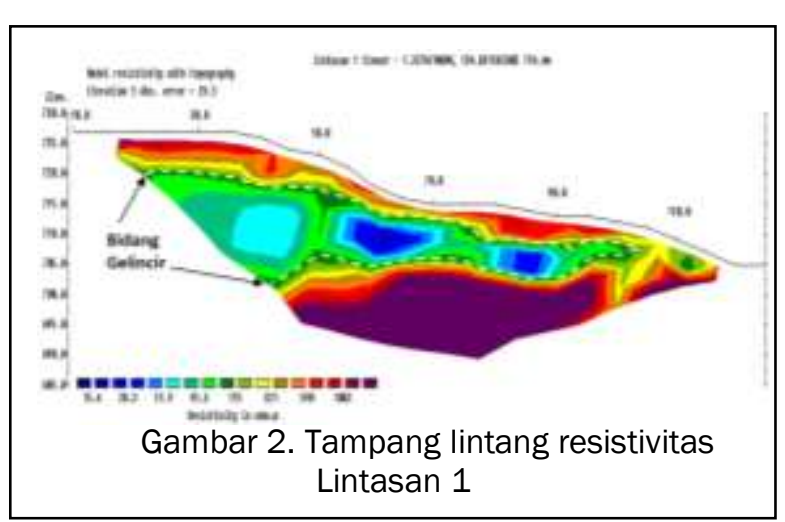

Lapisan tanah yang merupakan bidang gelincir tampak pada Gambar 2, bidang gelincir teridentifikasi dengan resistivitas 95,3 - $175 \Omega \mathrm{m}$, Lapisan tanah ini diinterpretasikan sebagai lempung, diperoleh 2 lapisan yang memanjang dari meter ke 20 sampai 110. Lapisan 1 mempunyai kedalaman $2,5-15 \mathrm{~m}$, sedang lapisan 2 kedalamannya 2,5 - $23 \mathrm{~m}$.

Tampang lintang lintasan 2 pada Gambar 3 memperlihatkan 3dimana terdapat bidang gelincir. Lokasi 1 terletak pada meter ke 20 - 35 dengan kedalaman 10 - $17 \mathrm{~m}$, lokasi ke 2 pada meter ke 45 - 105 dengan kedalaman $\leq 20 \mathrm{~m}$, sedang lokasi ke 3 pada meter ke110 - 117 dengan kedalaman $\leq$ $7,5 \mathrm{~m}$.

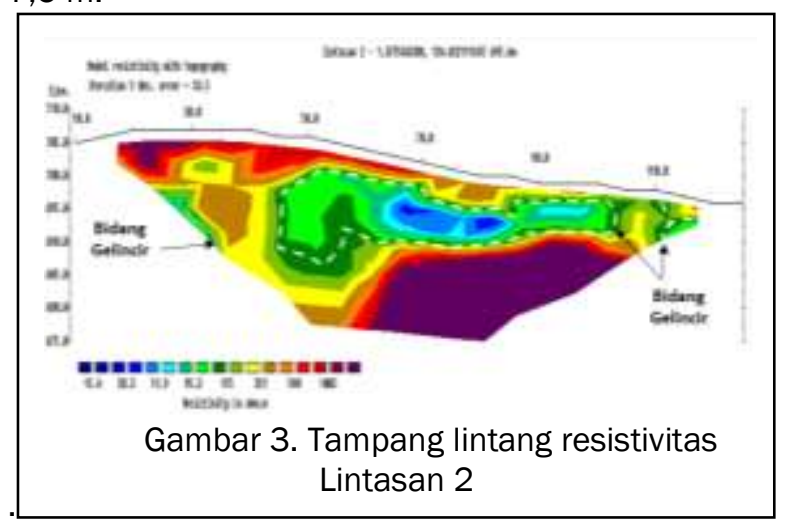

Tampang lintang lintasan 3 pada Gambar 4 memperlihatkan tampang lintang dimana terdapat bidang gelincir. Lokasi 1 terletak pada meter ke 15 - 100 dengan kedalaman $\leq 6 \mathrm{~m}$, Lokasi 2 terletak pada meter ke $30-110$ dengan kedalaman $\leq 15 \mathrm{~m}$.

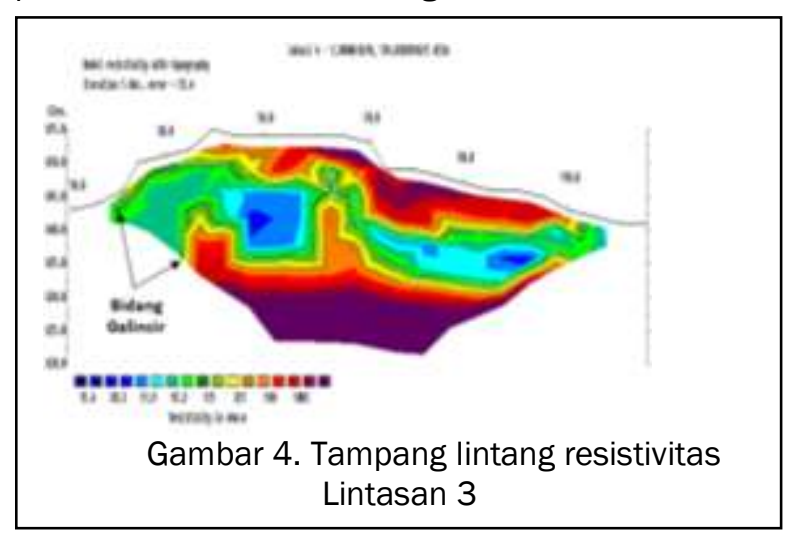


Tampang lintang lintasan 4 pada Gambar 5 memperlihatkan dimana terdapat bidang gelincir. Lapisan 1 terletak pada sepanjang lintasan dengan kedalaman $\leq 7 \mathrm{~m}$, lapisan ke 2 pada sepanjang lintasan dengan kedalaman 7 - $17 \mathrm{~m}$.

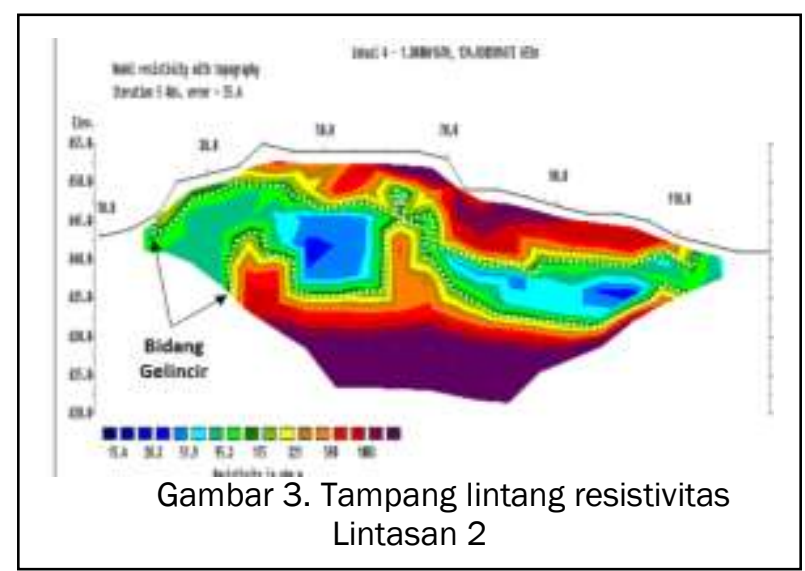

Pada semua lintasan teridentifikasi lapisan yang diinterpretasikan sebagai bidang gelincir. Kondisi lokasi penelitian mempunyai kemiringan curam, dengan tutupan vegetasi rapat. Keberadaan vegetasi menahan air hujan yang turun tidak kontak langsung dengan tanah, dan menahan aliran permukaan run off air yang akan mengakibatkan erosi. Sehigga keberadaan vegetasi memberikan kontribusi menahan dan mengikat massa tanah di atas lapisan bidang gelincir.

\section{Kesimpulan}

Teridentifikasi lapisan bidang gelincir dengan resistivitas (30 - 215) $\Omega \mathrm{m}$, yang merupakan lapisan lempung pasiran. Bidang gelincir ditemukan pada semua lintasan, pada lintasan 1, 3 dan 4 terdapat 2 lapisan dengan kedalaman sampai $23 \mathrm{~m}$. Lintasan 2 bidang gelincir teridentifikasi tersebar pada 3 lokasi dengan kedalaman mencapai $20 \mathrm{~m}$.

\section{Daftar Pustaka}

Alleoti, P. A. 2004. Warning System for RaifallInduced Shalow Failures. Elsevier. 73:247-265

Ao, M., Zhu, J., Wang, C., Yu, X. 2014. Identification of Landslide Region Based on Topographyc and Change Information. International Journal of Signal Processing, Image, and Pattern Recognition. 7:121-134.

Husain, M., As'ari, Seni, H. J. T. 2017. Pemetaan Akuifer Air Tanah Menggunakan Metode Golistrik Tahanan Jenis Konfigurasi Dipol-dipol Di Universitas Sam Ratulangi. Jurnal MIPA UNSRAT Online Vol. 6 No. 2.

Pareta, K. dan Pareta, U. 2012. Landslide Modeling and Susceptibility Mapping of Giri River Watershed. Himachal Pradesh (India). International Journal of Science and Technology. 1:91-104.

Seaton, William, J. and Burbey, Thomas, J. 2002. Evaluation of two-dimensional resistivity methods in a fractured crystalline-rock terrane. Journal of Applied Geophysics 51: 21-41.

Sugito, Zaroh, I., Indra, P. J. 2010. Investigasi Bidang Gelincir Tanah Longsor Menggunakan Metode Geolistrik Tahanan Jenis di Desa Kebarongan Kec. Kemranjen Kab. Banyumas. Berkala Fisika. Vol. 13, No. 2, April 2010, hal 49 - 54

Vardoulakis. 2002. Dynamic Thermoporoimechanical Analysis of Catastrophic Landslide. Geotecnique. 52:57-171. 